Kirja-arvio

\title{
Johdatus evolutionaariseen taloustieteeseen
}

Jussi Ahokas, yhteiskuntatieteiden maisteri, väitöskirjatutkija, yhteiskuntatieteiden ja kauppatieteiden tiedekunta, Itä-Suomen yliopisto

Matti Ylönen: Yhtiövalta alustatalouden aikakaudella - Evolutionaarinen taloustiede \& yhtiöt yhteiskunnallisina toimijoina. Vastapaino: Tampere, 322 sivua. 2021.

Helsingin yliopistossa maailmanpolitiikan yliopistolehtorina toimiva Matti Ylönen (VTT) on tutkinut monipuolisesti yhtiövaltaa ja yritysten poliittista taloutta. Ylösen vuonna 2018 Helsingin yliopiston väitöskirjapalkinnolla huomioitu väitöskirja käsitteli sangen kattavasti yhtiöiden vallankäytön kysymyksiä, vaikka se keskittyikin erityisesti yritysten verosuunnitteluun ja kansainväliseen sääntelyyn.

Ylösen syksyllä 2021 julkaistu tietokirja Yhtiövalta alustatalouden aikakaudella - Evolutionaarinen taloustiede \& yhtiöt yhteiskunnallisina toimijoina jatkaa samoilla urilla. Kirjalla on pitkä nimi, joka on sinällään varsin kuvaava. Teoksessa käydään kiinni kolmeen toisiinsa liittyvään kysymykseen: evolutionaariseen taloustieteeseen, yhtiövaltaan ja alustatalouteen. Taitavasti kaikki kolme isoa kysymystä kudotaan yhteen niin, ettei lukijan tarvitse missään vaiheessa jäädä arvuuttelemaan sitä, miten kirjan eri keskustelut liittyvät sen kokonaisargumenttiin. Vaikka yhtiövalta ja alustatalous on nostettu kirjan pääotsikkoon, teoksen tärkein anti liittyy evolutionaarisen taloustieteen esittelyyn suomenkielisille lukijoille. 
Ylösen lähestymistapa evolutionaariseen taloustieteeseen on kaksijakoinen. Hän esittelee kirjassaan tutkimussuunnan pääajatuksia, teorioita ja empiirisiä tutkimustuloksia mutta niiden rinnalla myös tieteensosiologisella otteella evolutionaarisen taloustieteen historiaa. Vaikka näin lavea rajaus saattaa tuntua äkkiseltään haastavalta, Ylönen onnistuu pitämään langat tiukasti näpeissään. Evolutionaarisen taloustieteen sisältöjen esittely etenee johdonmukaisesti, riittävän kronologisesti ja koko ajan ympäröiviä yhteiskunnallisia olosuhteita peilaten. Tähän käsittelyyn kytketään sulavasti myös evolutionaarisen taloustieteen kritiikki ja tutkimussuunnan häviäminen talous- ja yritystutkimuksen ytimestä.

Evolutionaarinen taloustiede on 1800-luvun lopussa erityisesti Yhdysvalloissa kehittynyt taloustieteen tutkimussuunta, jota on kutsuttu myös institutionaaliseksi taloustieteeksi. Ylönen käsittelee näitä synonyymeinä. Tutkimussuunnan keskeisiä kehittäjiä ovat olleet muun muassa Thorstein Veblen (18571929), John R. Commons (1862-1945), John Kenneth Galbraith (1908-2006) sekä paljon yhdessäkin julkaisseet Adolf Berle (1895-1971) ja Gardiner Means (1896-1988).

Ylösen määrittelyn mukaan evolutionaarisen taloustieteen peruslähtökohta on katsoa taloutta yli markkinoiden ja markkinamekanismin. Siis ymmärtää se, että "markkinat toimivat aina tiettyjen institutionaalisten käytäntöjen ja rakenteiden puitteissa, joita jatkuva yhteiskunnallinen ja taloudellinen muutos ravistelee" (Ylönen 2021, 15). Lisäksi Ylösen mukaan evolutionaarisessa taloustieteessä keskeistä on ajatus siitä, että talouden rakenteisiin liittyy aina valtaulottuvuuksia.

\section{Evolutionaarisen taloustieteen historiaa}

Evolutionaarisen taloustieteen historiasta piirtyy seuraavanlainen kuva. 1900-luvun alussa se kilpaili tasapäisesti marginalistisen taloustieteen kanssa siitä, miten taloutta - ennen kaikkea pohjoisamerikkalaista kapitalismia - ja yrityksiä tulisi tutkia. Historiallis-institutionaalinen ja abduktiivinen tutkimusote, jossa on vahva painotus empiriaan teorioiden muodostamisessa ja niiden testaamisessa, johti siihen, että evolutionaariselle taloustieteelle muodostui läheinen suhde käytännön talouspolitiikkaan ja populaariin talouskeskusteluun. 
Esimerkiksi Franklin D. Rooseveltin hallinnossa institutionalisteilla oli vahva asema: institutionalistisen taloustutkimuksen suuntauksesta nousseet politiikkasuositukset näkyivät selkeästi erityisesti 1930-luvun talouspolitiikan sekä yrityssääntelyn määrittelyssä. Keskeinen ajatus oli se, että valtion tehtävänä on aina aktiivisesti säädellä yritystoimintaa ja ennen kaikkea rajoittaa liiallisia valtakeskittymiä. Evolutionaaristen ajatusten vaikutusvalta ei juuri vähentynyt toisen maailmansodan seurauksena, mutta 1950-luvulta eteenpäin ne alkoivat vähitellen ajautua marginaaliin.

Yksi syy tähän Ylösen mukaan oli taloustieteen sisäinen tiedepoliittinen kamppailu. Erityisesti Chicagon yliopiston marginalistiselta pohjalta ponnistanut taloustiede George Stiglerin ja Milton Friedmanin johdolla otti tietoisesti evolutionaarisen taloustieteen keskeiset opinkappaleet, kuten myöhemmin esiteltävät hallinnoidut hinnat, ja tutkimustulokset hampaisiinsa. Vähitellen erityisesti yritystutkimuksen käytännöt muuttuivat abstraktien mallien rakenteluksi ja marginalististen periaatteiden seuraamiseksi. Taloutta jäsennettiin taas täydellisten markkinoiden toimintana, jossa yritykset maksimoivat voittoaan rajakustannushinnoittelua noudattaen. Toisin sanoen chicagolaiset saivat evolutionaarisesta taloustieteestä metodologisen niskalenkin.

Toki myös Yhdysvaltojen politiikassa puhalsivat samaan aikaan muutoksen tuulet, jotka lopulta nostivat Ronald Reaganin presidentiksi varsin yritysmyönteisellä tai ehkä paremminkin sääntelyvastaisella ohjelmalla. Ylönen ei pureudu kovin syvällisesti siihen, mikä oli chicagolaisten ajatusten rooli tämän poliittisen "vallankumouksen" taustalla. Hän tyytyy muistuttamaan, että isolla osalla Reaganin talousneuvoston jäsenistä oli kytkös Chicagon taloustieteen laitokselle.

Olivat tiedepoliittiset motiivit mitkä hyvänsä ja olivat niiden laajemmat yhteiskuntapoliittiset seuraukset millaisia tahansa, selvää on se, että monet kiinnostavat evolutionaarisen taloustieteen ideat ja näkökulmat ovat viime vuosina unohtuneet talouden ja yritysten tutkimuksessa. Ylösen mukaan tämä on harmillista, sillä monet niistä ovat edelleen käyttökelpoisia tämän päivän yritysten, monikansallisten yhtiöiden ja taloudellisten olosuhteiden analysoinnissa. Yksi kirjan päätehtävistä onkin kyseisten ajatusten kunnianpalautus. Kiinnostava havainto lienee se, että oikeastaan evolutionaarisen taloustieteen tuloksia ei koskaan kumottu niin, että ne olisi osoitettu empiirisesti paikkaansa pitämättömiksi tai teoreettisesti heikoiksi. Kuten sanottua, tutkimussuunta hävisikin ennen kaikkea metodologisen painin. 


\section{Evolutionaarisen taloustieteen ydinajatuksia - kuinka yritykset hinnoittelevat?}

Yksi evolutionaarisen taloustieteen ydinajatuksista, jonka Ylönen esittää edelleen käyttökelpoisena, on ajatus "hallinnoiduista hinnoista" (joskus "suunnitellut hinnat"). Ennen kaikkea Gardiner Meansin ja Adolf Berlen tutkimustyön ytimessä ollut idea tarkoittaa käytännössä sitä, että yritykset asettavat hinnat tuottamilleen hyödykkeille, sekä loppu- että välituotteille, hyvin monenlaisia motiiveja seuraillen. Esimerkiksi uusklassinen rajakustannushinnoittelu, jossa yritys asettaa hyödykkeen rajatulon vastaamaan sen rajakustannusta, on täten harvoin, jos koskaan, tarkka kuvaus yrityksen hinnoittelutavasta.

Hallinnoitujen hintojen teoria lähtee muun muassa siitä, ettei yrityksellä ole oikeastaan edellytyksiä toteuttaa rajakustannushinnoittelua, koska riittävää tietoa sen pohjaksi ei ole. Taloudessa vallitsevassa epävarmuudessa ja kilpailijoiden reaktioita jatkuvasti pohtien yritykset sen sijaan nojautuvat lähes aina jonkinlaiseen omakustannushinnoitteluun. Yritys siis arvioi tuottamansa hyödykkeen kokonaiskustannuksen ja asettaa sen päälle voittolisän, jonka se uskoo markkinoilta pystyvänsä saamaan - kilpailun asettamissa rajoissa. Ylipäätään yritysten hinnoittelu on kaikkea muuta kuin tempoilevaa, mitä muuttuvissa taloudellisissa olosuhteissa täysverinen rajakustannushinnoittelu helposti voisi olla.

Motiiveja, jotka vaikuttavat yrityksen hinnoitteluun, voivat olla esimerkiksi markkinoille pääsy, markkinoiden hallinta tai markkinasovun ylläpitäminen (Berle 1965). Yksi keskeinen ja yleisempi hinnoittelumotiiveihin vaikuttava tekijä on se, että modernit yritykset katsovat pitkälle tulevaisuuteen. Niiden keskeisenä toiminnan lähtökohtana on itsensä säilyttäminen. Hinnoittelupäätökset muodostuvatkin usein osaksi moninaista yhtiövallan käyttöä, jolloin niiden tulkitseminen puhtaana vapaiden markkinoiden teknisenä optimointiharjoituksena vähintäänkin sivuuttaa monia keskeisiä dynamiikkoja. On huomattava, että evolutionaarisen taloustieteen hinnoitteluteoria menee näiden dynamiikkojen avaamisessa vieläkin pidemmälle kuin esimerkiksi marxilaiskeynesiläinen monopolistinen tai oligopolistinen hinnoitteluteoria. 


\section{Lisänäkökulmia yhtiövallan analyysiin}

Vaikka Ylösen kirjassa nimenomaan hintojen hallinnointi nostetaan yhtiövallan käsittelyssä jalustalle, kirjassa tarkastellaan yhtiövaltaa myös laajemmin. Yhtiövalta on tietysti muutakin kuin hinnoittelua. Esimerkiksi Ylösen aiemmin urallaan tutkima verovälttely, kirjanpitokonstein tapahtuva voittojen siirtely ja moninainen yritysten toimintaedellytyksiin liittyvä lainsäädäntövaikuttaminen ovat esimerkkejä siitä, kuinka yhtiöt käyttävät laajempaa yhteiskunnallista valtaa tai hyödyntävät lainsäädännössä olevia porsaanreikiä omiksi eduikseen. Nämä käytännöt ovat liittyneet viime vuosikymmeninä ennen kaikkea monikansallisiin yrityksiin, joiden tutkimukseen evolutionaarisella taloustieteellä on myös paljon annettavaa. Tämän tekee selväksi Ylösen kirjan neljäs luku, joka käsittelee monikansallisia yhtiöitä ja nojaa ennen kaikkea Richard Barnetin ja Ronald Müllerin työn esittelyyn.

Kansainvälinen sääntely-ympäristö ja siinä tapahtuneet muutokset ovat Ylösen mielestä laajemminkin kiinnostava näkökulma yritysten vallankäytön muotoihin. Tällä tavalla yritysvalta ja maailmanpolitiikka kietoutuvat yhteen. Ylönen tarkastelee tätäkin kysymystä ennen kaikkea tutkimuksen näkökulmasta. Kun yleisemmässä yritysten analyysissa hallinnoitujen hintojen näkökulma unohdettiin, vastaavalla tavalla monikansallisten yhtiöiden ja kansainvälisen sääntelyn tutkimuksen kentällä niin sanottu yritysvastuututkimus syrjäytti viimeistään 1990-luvulla aiemmat evolutionaarisesta taloustieteestä ponnistaneet tutkimussuunnat. Ylönen pitää keskeisenä syynä tälle YK:n sisällä tapahtunutta muutosta.

Ylönen esittää kirjassaan, että 1970-luvulla suomalaisen Klaus Sahlgrenin luotsaaman ylikansallisten yritysten tutkimuskeskuksen UNCTC:n tutkimuksella oli aluksi erittäin suuri vaikutus siihen, mitä kansainvälisestä sääntelyjärjestelmästä ajateltiin. Oikeastaan tätä tutkimusohjelmaa voidaan pitää viimeisenä merkittävänä toteutuneena evolutionaarisen taloustieteen tutkimusohjelmana. 1980-luvulla yleinen poliittisen ilmapiirin muutos ja kilpailevat ohjelmat, muun muassa OECD:ssä, kuitenkin sammuttivat tämän viimeisenkin liekin, ja UNCTC lakkautettiin vuonna 1992. Ylösen tulkinnan mukaan yritysvallan tutkimukseen syntyi tämän seurauksena tieteellinen tyhjiö, jonka yritysvastuuseen liittyvä tutkimus 1990-luvun edetessä vähitellen täytti. 
Yritysvastuututkimuksen keskeinen ongelma oli Ylösen mukaan se, että edes huippukautenaan tutkimus ei pystynyt tarjoamaan eväitä sillä hetkellä havaittujen yritysten toimintaan liittyvien tilanteiden tulkintaan. Parmalatin, WorldComin ja Enronin skandaalit osuivat juuri näille vuosille, ja yhtiövallan tutkimus näytti täysin kyvyttömältä kertomaan, mistä oli kyse. Ylönen pitää selvänä, että jos perinteinen evolutionaarinen taloustiede olisi vielä ollut voimissaan, vastaavaa epätietoisuutta ei olisi päässyt syntymään.

\section{Alustatalous ja evolutionaarinen taloustiede tänään}

Viimein päästään kirjan kolmanteen pääteemaan eli alustatalouteen. Sen tiivis käsittely vahvistaa lukijalle sen, että hänen käsissään ei ole varsinaisesti kirja alustataloudesta vaan siitä, miten yhtiövaltaa voidaan nykyisen alustataloudeksi kutsutun talousmallin aikakaudella analysoida evolutionaarisen taloustieteen välinein.

Ylösen (2021, 247) määrittelyssä alustataloudella on kolme kivijalkaa: globaalit arvoketjut, niitä täydentävät varallisuusketjut sekä liiketoiminnan nivoutuminen digitaalisiin alustoihin. Tätä seuraa analyysi, jossa arvoketjuja puretaan analyyttisesti osiin hallinnoitujen hintojen, verkostorakenteiden (alihankinnan) ja keskittymisen näkökulmien kautta. Varallisuusketjuja puolestaan analysoidaan hallinnoitujen hintojen, sääntelyjärjestelmien logiikoiden ja monipuolisen yhtiösuunnittelun näkökulmien kautta. Lopuksi alustatalouden liiketoiminnan perusteita tarkastellaan hallinnoitujen hintojen, fundamentaalisten resurssien omistamisen, kuten datan ja infrastruktuurin, ja suoremman vallan käytön, kuten lobbauksen ja oikeustoimien, näkökulmien kautta.

Jäsennys on mielenkiintoinen ja tukee yhtä kirjan pääväitteistä: evolutionaarisen taloustieteen hallinnoitujen hintojen näkökulma on yhä edelleen käyttökelpoinen analyysityökalu yhtiövallan tarkastelussa. Kirjan alustatalouden analyysissa jää kuitenkin hieman epäselväksi, mitkä osat siitä nojaavat suoraan, mitkä epäsuoremmin ja mitkä eivät ehkä lainkaan evolutionaarisen taloustieteen perinteeseen.

Kirjan lopussa Ylönen korjaa hieman tätä puutetta pohtimalla eksplisiittisesti sitä, miten tämän ajan suuryhtiöitä pitäisi tutkimuksellisesti lähestyä. Hieman puskista hän nostaa evolutionaarisen taloustieteen pitkän tutkimuslinjan 
rinnalle nyt jälkikeynesiläisen taloustieteen suuntauksen, jonka perusta on John Maynard Keynesin (1936) pääteoksessaan The General Theory of Employment, Interest and Money esittämissä taloustieteellisissä ideoissa. Metodologinen yhteys näiden tutkimussuuntien välillä on toki olemassa: molemmat hylkäävät metodologisen individualismin sekä vahvan instrumentalismin ja painottavat taloudellisiin ilmiöihin liittyvää fundamentaalista epävarmuutta.

Jos tämä on metodologinen tie eteenpäin, mitkä sitten ovat ne temaattiset lähtökohdat, joiden kautta yrityksiä ja yhtiövaltaa tulisi jatkossa tutkimuksellisesti tarkastella? Näitä ovat Ylösen mukaan yritysten hinnoitteluprosessit, niihin liittyvät valtasuhteet niin yhtiöiden sisällä kuin niiden ulkopuolella, suuryritysten pyrkimys "kaiken" kontrollointiin ja markkinoiden keskittymistendenssi - myös maantieteellisessä mielessä.

Matti Ylönen tuo kirjallaan evolutionaarisen taloustieteen Suomeen noin 450 kirjallisuuslähteen saattelemana. On kiinnostavaa nähdä, syntyykö tulevina vuosina Suomessa poliittisen talouden tutkimuksen tai taloustieteen kentälle tutkimushankkeita, jotka lähtevät edistämään edellä hahmoteltua tutkimusagendaa päivittäen samalla evolutionaarisen taloustieteen vanhoja teorioita nykypäivään. Jos näin käy, on mahdotonta kiistää Ylösen kirjan vaikutusta tuollaisen prosessin syntyyn.

\section{Lähteet}

Berle, Adolf A. 1965. The impact of the corporation on classical economic theory. The Quarterly Journal of Economics, 79:1, 25-40.

Keynes, John Maynard. 1936. The general theory of employment, interest and money. Lontoo: Macmillan.

Ylönen, Matti. 2021. Yhtiövalta alustatalouden aikakaudella - Evolutionaarinen taloustiede \& yhtiöt Yhteiskunnallisina toimijoina. Tampere: Vastapaino. 